\title{
Discussion on the Integration of Environmental Art Design and Traditional Culture
}

\section{Weiqun Qian}

Shanghai Research Institute of Publishing and Media, Shanghai Publishing and Printing College, Shanghai 200093, China.

Abstract: China has a long history of development, and a large number of classic cultures have been produced during the development of more than 5000 years. These traditional cultures still have great significance in promoting the development of social economy, politics, culture and many other fields. Inheriting and integrating traditional culture in environmental art design, highlighting national characteristics, endowing environmental art design with tenacious vitality and cohesion, has achieved remarkable results. This paper focuses on the integration of environmental art design and traditional culture.

Keywords: Environmental Art Design; Traditional Culture; Integration; Discussion

With the continuous development of economic globalization, the competition among countries is becoming increasingly fierce, and the development of all walks of life is facing severe challenges. If the environmental art design industry wants to stand out in the fierce competition, it should pay attention to absorb nutrition from traditional culture, and skillfully combine with the era elements to design environmental art design works with Chinese characteristics, so as to improve the comprehensive strength, as well as inherit and carry forward the traditional culture. Next, talk about the integration of environmental art design and traditional culture.

\section{The development of environmental art design in China}

With the development of economy and society, the progress of modern science and technology, people's material living standard is constantly improving, and the living environment and spiritual living standard have higher pursuit. Due to the influence of many environmental factors, there are many development problems in domestic environmental art design. It is embodied in the following aspects:

First, with the accelerating process of world integration, Western ideology and design concept have seriously impacted the ideas of domestic designers. Some designers blindly praise western design concepts and directly copy and paste them into domestic environmental art works. Although they can meet people's needs in a short period of time, they are not in line with China's national development strategy and urban construction concept, which is disadvantageous for long term development. Many designers are lack of scientific and reasonable design of human landscape, which leads to low matching rate with urban environment design and insufficient control of urban environment that leads to various problems. At present, the environmental art design concept of western developed countries cannot adapt to China's basic national conditions, and many environmental art designers are not optimistic about the use of traditional cultural elements. They mistakenly believe that traditional culture belongs to feudal cultural ideas, and will not infiltrate traditional cultural concepts in environmental art design, so that rarely add regional cultural features, which is not conducive to our cities long term development of construction.

Copyright(C 2020 Weiqun Qian

doi: 10.18686/ahe.v4i10.2910

This is an open-access article distributed under the terms of the Creative Commons Attribution Non-Commercial License (http://creativecommons. org/licenses/by-nc/4.0/), which permits unrestricted non-commercial use, distribution, and reproduction in any medium, provided the original work is properly cited. 
Second, since the 21st century, with the continuous progress of China's society, people's aesthetic concept has changed. Traditional cultural elements are gradually seen in the environmental art design, but most of them appear in the environmental art design of rural and small towns. Due to the economic backwardness and information blocking, many remote mountainous areas passively retain the traditional cultural elements. However, it is still rare in urban construction, especially in large cities with economic development. People advocate the concept of modern information technology, and traditional cultural elements become dispensable. The main reason is that designers have little understanding of traditional culture and feel strange to it, so they don't know how to use it effectively. By invasion of the western culture to our country, many urban environmental art design, although part of the use of the concept of the combination of Chinese and western, in a large number of use of western design ideas, often only vaguely symbolic embellishment of traditional cultural elements. It did not display the true advantages and essence of traditional culture.

Third, China's traditional culture is the crystallization of hard work and wisdom of the working people over the past 5000 years. It is closely related to people's production and life, and it is easy to arouse people's emotional resonance. The infiltration of traditional cultural elements into environmental art design is conducive to improving the vitality and cohesion of environmental art works, and constantly increasing the harmony and nationality of environmental art design, especially in the era of "fast food culture" prevalence. The national spirit and Chinese cultural spirit can be carried forward, and people's art appreciation ability can be improved to a great extent. Therefore, it is very important to infiltrate traditional cultural elements into environmental art design.

\section{Specific countermeasures for the integration of environmental art design and traditional culture}

\subsection{Directly copy and paste traditional culture elements directly}

Under the new situation, the integration of traditional cultural elements in environmental art design can outline a new visual image, and convey new thoughts and feelings to the audience. Secondly, designers can also combine the actual situation to effectively innovate the traditional cultural elements and integrate the elements of the times, so that the final environmental art works image has the shape and charm of traditional culture and the form and connotation of modern art, in order to fully show the regional characteristics, national ideas and spirit. In the process of creation, if conditions permit, designers can directly use traditional graphics, apply traditional graphics to new carriers, and present another visual language environment for the public. This can not only give full play to the significance and value of traditional graphics, but also fully display the shaping and expressive power of traditional cultural elements, so as to continuously improve the quality and level of environmental art design. For example, many financial departments, banks and other financial institutions will put a stone lion in front of the gate. Stone lions are widely used as architectural ornaments in traditional society. For example, stone lions are used in ancient palaces, bridges and other places to show peace and auspiciousness. They not only meet the aesthetic requirements, but also meet the needs of people. The application of stone lions in environmental art design can enrich the connotation of artworks.

\subsection{Refining traditional culture}

With the acceleration of the process of world integration, all walks of life should pay attention to carry forward the national spirit and traditional culture in the development process. As far as environmental art design is concerned, designers should extract traditional cultural elements related to environmental art design from a large number of traditional cultural elements, and transform and refine these elements in combination with actual needs, using modern design and aesthetic concepts, so as to not only for own use, but also tap the essence of traditional culture and strengthen the Eastern and Western cultures in order to Integrate with each other to create environmental art works with traditional culture and characteristics of the times. For example, during the construction of Shanghai Jinmao building, the designers applied the "tower" structure concept of traditional culture to modern architecture, and optimized the tower structure based on aesthetics and mechanics, highlighting the beauty of the outline and rhythm of the building, which is still a representative case in the history of architecture

\subsection{Pay attention to inheritance and innovation of traditional cultural elements}

In the process of modern environmental art design, designers should pay attention to the inheritance of traditional cultural 
elements, realize the combination with modern aesthetic culture, so as to endow environmental art design works with modern architectural style characteristics, at the same time, they can also highlight the traditional cultural connotation and implication, infiltrate the excellent cultural connotation and value concept into the works, and pass on the correct value to the public through the environmental art works concept. Specifically, in order to achieve the innovation of traditional cultural elements, we should focus on highlighting national characteristics, times characteristics and traditional cultural elements in the process of modern environmental art design. For example, Suzhou museum buildings have a high evaluation in the world, which is the inheritance and innovation of traditional cultural elements. Designers have a deep understanding of the connotation of traditional cultural heritage. With humanistic care, they comprehensively use modern environmental art design concept and ancient garden design concept to design and build a modern museum. The museum is located in the ancient city of Suzhou, and complements the Zhongwang mansion, creating a harmonious architectural atmosphere. The interior of the museum adopts modern elements, which take on an altogether new aspect. Another example is the construction of the Confucius Institute building complex in Qufu, Shandong Province, which is a typical case of deepening innovation and inheriting the connotation of traditional culture. The building complex of Confucius Institute complements the "academy" form in ancient China, with ingenious layout and innovative conception. The buildings are surrounded by mountains and rivers on both sides, which coincide with the geomantic theories of ancient China, such as "backed by mountains" and "surrounded by gold belts". The whole building complex integrates a variety of traditional architectural cultural elements, and also conforms to the modern environmental art design concept In the actual design process. Designers refine and innovate the traditional cultural elements based on the modern aesthetic concept and design concept. To a large extent, the deep integration of traditional culture and the characteristics of the times have been realized, and the quality and level of environmental art design have been continuously improved.

\section{Conclusion}

To sum up, with the accelerating process of world integration, many cultural elements of various countries are gradually converging. In order to maintain national characteristics and carry forward and inherit excellent traditional culture more effectively, we should pay attention to the integration of traditional cultural elements in the process of modern environmental art design. Integration method should be chosen according to the actual situation, which can be copy and paste, select and refine, or innovation and inheritance. But generally speaking, in the design process, we should, based on the actual situation, follow the design purpose and concept of modern environmental art, deeply excavate and infiltrate the connotation and value orientation of traditional culture, so as to create more excellent environmental art products.

\section{References}

1. Lv P. Research on the integration of environmental art design and traditional cultural elements in public space of urban rail transit station in China. Modern Horticulture 2017; (02): 100-101.

2. Ding Y. Analysis on the integration of environmental art design and traditional culture. China's Interior Decoration World 2018; (003): 151.

3. Gao L. On the integration of environmental art design and traditional culture, Art Technology 2017; (23): 253.

4. Chen C. On the application of Chinese traditional cultural elements in modern environmental art design. Packaging World 2014; (004): 104-105.

5. Ping J. The return of Chinese traditional culture in modern environmental art design, Intelligence 2014; (29): $273+275$. 